\title{
Inside the Black Box of Strategy: Sequential Synthesis
}

\author{
Marc G. Baaij \\ Rotterdam School of Management
}

\begin{abstract}
The hallmark of strategic decisions is their interdependence: competitive advantage requires that these decisions reinforce each other. However, mutual reinforcement requires a synthesis of decisions. There are many strategy tools for analysis but not for synthesis. Performance landscape modeling of decision combinations has its value for academic research but is too complex for practice. This working paper proposes a sequential, judgment-based, qualitative modeling process for strategy synthesis. Whereas performance landscape models use binary, quantitative decision values, and computer simulations, the proposed process uses qualitative values and managerial judgment. By simplifying the synthesis, this working paper contributes to strategy practice.
\end{abstract}

Keywords: strategy, synthesis, decision interdependence, consistency assessment, morphological analysis 


\section{INTRODUCTION}

A strategy is "the smallest set of choices to optimally guide (or force) other choices" (Van den Steen, 2017, p. 2616). The hallmark of strategic choices or decisions is their interdependence (Leiblein, Reuer \& Zenger, 2018). Competitive advantage depends on the mutual reinforcement of the strategic decisions (Leiblein et al., 2018).

This mutual reinforcement requires a synthesis. However, strategy synthesis represents an elusive "black box" in the strategy literature (for reviews, see Burgelman, Floyd, Laamanen, Mantere, Vaara \& Whittington, 2018; Laamanen, 2017). Strategic planning lacks a deliberate process for synthesis (for a review, see Wolf \& Floyd, 2017). A review of strategy tools (Vuorinen, Hakala, Kohtamäki, \& Uusitalo, 2018) identifies various tools for analyzing the fit between organization and environment, but none of them guides the synthesis. Therefore, strategy synthesis has to depend on imagination, experimentation, and chance.

As the search for the peak on a performance landscape, performance landscape modeling considers the combination of interdependent choices that form a strategy (for an overview, see Baumann, Schmidt \& Stieglitz, 2019). While valuable for academic research, the computer simulations, even with binary decision values $(0,1)$, are too complex for practice (Rivkin, 2000).

The purpose of this working paper is to explore the possibilities for a simple strategy synthesis process. The research question is: How can actors assess the interdependence between strategic choices and create a reinforcing configuration of these choices in a simple manner?

Performance landscape modeling originated from evolutionary biology; an alternative modeling approach in that field is "morphological analysis," or the study of structural interrelationships between organisms (Ritchey, 2013). While performance landscape modeling 
uses quantitative binary decision values and computer simulation, general morphological analysis or GMA (Ritchey, 2013) utilizes qualitative decision alternatives and human judgment to assess the consistency of combinations of decisions. The main simplification principle in GMA is sequencing: Instead of simultaneous assessment of all possible relationships between all decisions, GMA sequentially compares pairs of decision values. This working paper's main contribution is translating GMA to a sequential, judgment-based, qualitative modeling process for strategy synthesis. This process aims to increase the efficiency and effectiveness of strategy synthesis.

The structure of this working paper is as follows. The following section identifies the strategic choices and sub-choices. After that, we describe the process for combining values of subchoices into a consistent choice configuration. The following section outlines how to combine choice configurations into a consistent strategy configuration. The working paper ends with a discussion and a conclusion.

\section{IDENTIFICATION OF THE POSSIBLE VALUES OF THE SUB-CHOICES OF A STRATEGY-CONFIGURATION}

The strategy tool closest to the synthesis process is the "Strategy Diamond" (Hambrick \& Frederickson, 2001). It visualizes the configuration of decisions but does not guide how to configure them. Strategy formation begins with identifying the (sub-) choices and then consistently combining them. Decomposition of a complex whole into simpler elements is an essential principle of the design of complex systems (Simon, 1962); choices are the simpler elements of strategy.

Building on the "Strategy Diamond" (Hambrick \& Frederickson, 2001) and the "ValueBased Strategy" framework (Brandenburger \& Stuart, 1996), I distinguish between four choices: 
arena, customer value proposition, value creation model, and value capture model. This configuration of four choices represents the highest level of abstraction. We decompose these four choices into sub-choices. The subjects of the (sub-) choices are variables.

According to the "problem-finding and problem-solving" approach, firms can create value by identifying and solving problems (e.g., Baer, Dirks \& Nickerson, 2013; Felin \& Zenger, 2016; Nickerson \& Zenger, 2004). If we apply this approach to strategy formation, the question becomes: What value(s) of a strategic variable contribute to the solution of the strategic problem? Each subchoice is a variable whose values should contribute to that solution; moreover, the values of the sub-choices should reinforce each other.

We illustrate the synthesis process with a fictive, stylized case about a business school (hereafter, "focal B-school"). Focal B-school is a prestigious, top-ranked school offering degree programs and executive education to develop global business leaders. The case focuses on the disruption to higher management education resulting from the introduction of digital technology. The board perceives digital disruption to be a strategic problem. It formulates a question to guide its problem-solving efforts: "How should the focal B-school respond to the digital disruption of higher management education to continue to develop global business leaders profitably? " Figure 1 presents how we decompose the strategic choices can into sub-choices. The number of subchoices may vary by choice.

Insert Figure 1 here: Lower the level of abstraction to identify the interdependent sub-choices 
Is the search for a consistent configuration of 16 values feasible? We might identify an analogical case with a configuration that we can simulate. We additionally might imagine a complete configuration or, by chance, encounter a consistent configuration. However, the odds of finding or imagining a complete configuration are small. A bottom-up approach that begins with the values of sub-choices provides better odds. To generate possible values for the individual sub-choices, We may use, for example, deductive reasoning, heuristics, analogical reasoning, imagination, and physical experimentation. The search for these values is beyond the scope of this working paper.

\section{FIRST SYNTHESIS ROUND: COMBINE VALUES OF SUB-CHOICES INTO A CONSISTENT CHOICE-CONFIGURATION}

In the illustrative case, we combine the values of 16 sub-choices. To simplify the combinatory process, we divide it into two rounds: in the first round, we combine sub-choices into a consistent choice configuration. Because there are four choices, the first round comprises four combinatory processes. In the second round, we combine the four configurations into a consistent strategy configuration.

We illustrate the combinatory process with the example of the arena choice. This choice was decomposed into four sub-choices (see Figure 1), implying six possible mutual relationships between them. The simultaneous assessment of six relationships is too complex. Therefore, GMA suggests assessing only one pair of sub-choices (that is, one relationship) at a time.

For this pairwise assessment of the consistency of possible values, GMA uses a so-called "cross-consistency assessment matrix" (hereafter, CCA; see Figure 2). Each pair of sub-choices is a so-called "choice block." This matrix bears similarities to other matrices: the "influence matrix" 
or "interaction matrix" of decision choices that can model organizational adaptation (Ethiraj \& Levinthal, 2004), the "adjacency matrix" for choice interaction in strategy making (Ghemawat \& Levinthal, 2008), or the "design structure matrix" used for product development (Steward, 1981).

Insert Figure 2 here: Combine sub-choices into a consistent choice configuration: Example of the arena.

\section{First Step: Assess the Consistency of the First Two Sub-Choices}

In the first step, we assess the consistency of the possible values of the first and second sub-choice of the arena. The top-left choice block represents this pair in the matrix (see Figure 2). GMA suggests four evaluation criteria for qualitative assessment or judgment of the consistency of the values (Ritchey, 2015).

First, we assess the logic of the combination of these two values. The combination of values may be a logical contradiction: here, we may use strategy frameworks. We compare the focal relationship with the theoretical relationship. Second, we assess the empirical compatibility of the values. A combination of values may be improbable, given empirical evidence: that combination is never, or very rarely, seen in practice. Third, we consider the existence of normative constraints. Does this combination of values conflict with any norms? Fourth, we consider user-defined constraints of the focal organization. The assessment of the relationship between the values of the two sub-choices can vary from very negative (the values strongly conflict with each other) to very positive (the values strongly reinforce each other). A pair of values must fit all four criteria to qualify as consistent. 
We indicate the assessment in the form of a sign in the relevant cell in the matrix. In Figure 2, for simplicity, we use only one indicator for the assessment. If the assessment is positive, i.e., the values are consistent, we mark the cell with a "V"; in all other cases, we leave the cell empty. In this example, we assess all pairs of values as consistent. However, there may be no consistent pair in the matrix. Then we add lower-ranked values (from my search for possible values) to the matrix until I find at least one consistent pair.

\section{Second Step: Assess the Consistency of the First Three Sub-Choices}

Next, we select the third sub-choice of the arena: in the illustrative example, the customer range. To illustrate the process, we select one pair of offerings ranges and formats. The selected offerings range is "only education services," and the selected offerings formats are: "services" and "servicesas-a-product"; in this case, specifically, education services and education-services-as-a-product. The "V" sign of this selected pair has a circle in Figure 2.

We use the possible values of the third sub-choice to conduct a twofold consistency assessment. We assess the consistency of the possible values of the third choice and both the selected value of the first choice and the selected value of the second choice. The two-fold assessment takes place in two sub-steps. The first sub-step (Step 2a in Figure 2) assesses the consistency of the selected value of the offerings range and the possible values of the customer range. Following the previously outlined approach, we assess two possible values of the customer range as being consistent with "education only," namely "only students" and "students and schools." In the second sub-step (Step $2 \mathrm{~b}$ in Figure 2), I assess the consistency of the selected value of the offerings formats and the possible values of the customer range. We find all four possible 
values of the customer range to be consistent with "services" and "services-as-a-product." Both "only students" and "students and schools" meet the two-fold consistency assessment. The example uses "students and schools" as the selected value of the third sub-choice (see the circled V-mark in the two cells in Figure 2).

\section{Third Step: Assess the Consistency of the Four Sub-Choices}

We now add the fourth and final sub-choice of the arena, which is "customer segments." We use the possible values of the customer segments sub-choice to conduct a threefold consistency assessment. We assess the consistency of the values of the fourth sub-choice with the selected values of the consistent configuration of the first three sub-choices. The threefold consistency assessment comprises three sub-steps: in the first sub-step (Step 3a in Figure 2), I assess the consistency of the possible values of the customer segments and the selected value of the offerings range. In the second sub-step (Step $3 b$ in Figure 2), I assess the consistency of the possible values of the customer segments and the selected value of the offerings formats. In the third sub-step (Step 3c in Figure 2), I assess the consistency of the possible values of the customer segments and the selected value of the customer range. Two values of the customer segments meet the threefold consistency assessment. The example uses "top and middle segment" as the selected value of the fourth sub-choice (see the three circled V-marks in Figure 2). This selection completes a consistent arena-configuration of sub-choices, to which we assign the following label: "Expand to serve other schools."

We repeat the process of combining sub-choices to create other consistent arena configurations. In this example, we identify four alternative arena configurations (not discussed in 
this working paper). We repeat the same combinatory process for the other three strategic choices. After the first round, we have one or more consistent configurations for each choice.

\section{SECOND SYNTHESIS ROUND: COMBINE VALUES OF CHOICE-CONFIGURATIONS INTO A CONSISTENT STRATEGY-CONFIGURATION}

The second round combines choices into a strategy. Like the first round, we assess the consistency of the choices in three steps (see Figure 3). Again, we perform a pairwise consistency assessment of the possible values of the choices. Each possible value of each choice is a configuration of values of the sub-choices. The values of these sub-choices are not shown in the second-round matrix because this would make the matrix unreadable.

Insert Figure 3 here: Combine choices into a consistent strategy-configuration

Since the process is like the first round, we shall not repeat it. However, we elaborate on the pairwise assessment of choices because it differs from the sub-choices. The relationship between the two choices depends on the relationships between the underlying sub-choices. Therefore, we decompose the consistency assessment of the two choices into the consistency of sub-choices of the first and the second choice. We can visualize these pairs of "sub-choice values" in a separate choice block (not shown in this working paper) that combines the values of the sub-choices of one choice with those of the other choice. Then we perform a pairwise consistency assessment of the 
value of a specific sub-choice of the first choice and a value of a specific sub-choice of the second choice.

\section{DISCUSSION AND CONCLUSION}

The proposed synthesis process liberates actors from dependence on imagination, experimentation, or chance in creating a strategy synthesis. Nevertheless, imagination, experimentation, or chance keep their value. They can also contribute to the generation of values for (sub-) choices. Individual actors may like the proposed process because it is relatively easy to understand and use. Organizations may benefit as well from this systematic approach to strategy synthesis. The explicitness of the process facilitates cooperation between participants: it is not a tacit, "black box" process that occurs in the mind of an individual actor.

Moreover, we could consider the CCA matrix a boundary object (Spee \& Jarzabowski, 2009); it allows for a collective process, engaging relevant stakeholders in an "inclusive" approach to strategy formation. The transparency of the process also allows the actors to persuade relevant stakeholders better than a tacit, "black box" synthesis to approve or accept a new strategy and motivate these stakeholders to implement this strategy. The transparency of the proposed process may also help to resolve disputes between actors about strategic choices. The synthesis process allows for a transparent assessment of the consistency of alternative combinations, including those of the opposition.

Research has drawn attention to differences between the actual and intended use of strategy tools (Jarzabkowski \& Kaplan, 2015). By describing the process as precisely as possible, we try to minimize ambiguity. However, we cannot rule out interpretive flexibility. We recognize that the 
process, while simple, requires much effort from the user. Actors may therefore cut corners. For example, instead of an extensive assessment based on the four criteria, the consistency of pairs can also be assessed more quickly. Moreover, actors may decide to skip the first round to combine choices instantly.

"The dirty little secret of the strategy industry is that it does not have any theory of strategy creation" (Hamel, 1997, p. 80). A possible explanation for the absence of such a theory is the complexity of the synthesis process. Strategy practice may benefit from the proposed, simple process because this complexity has only increased since Hamel's statement. 


\section{REFERENCES}

Baer, M., Dirks, K. T., \& Nickerson, J. A., 2013. Microfoundations of strategic problem formulation. Strategic Management Journal, 34(2), 197-214.

Baumann, O., Schmidt, J., \& Stieglitz, N., 2019. Effective search in rugged performance landscapes: A review and outlook. Journal of Management, 45(1), 285-318.

Brandenburger, A. M., \& Stuart Jr, H. W., 1996. Value-based business strategy. Journal of Economics \& Management Strategy, 5(1), 5-24.

Burgelman, R. A., Floyd, S. W., Laamanen, T., Mantere, S., Vaara, E., \& Whittington, R., 2018. Strategy processes and practices: Dialogues and intersections. Strategic Management Journal, 39(3), 531-558.

Ethiraj, S. K., \& Levinthal, D., 2004. Bounded rationality and the search for organizational architecture: An evolutionary perspective on the design of organizations and their evolvability. Administrative Science Quarterly, 49(3), 404-437.

Felin, T., \& Zenger, T. R., 2016. Crossroads-Strategy, problems, and a theory for the firm. Organization Science, 27(1), 222-231.

Ghemawat, P., \& Levinthal, D., 2008. Choice interactions and business strategy. Management Science, 54(9), 1638-1651.

Hambrick, D. C., \& Fredrickson, J. W., 2001. Are you sure you have a strategy? Academy of Management Perspectives, 15(4), 48-59.

Hamel, G. 1997, June 23. Killer strategies that make shareholders rich. Fortune, 70-88.

Jarzabkowski, P., \& Kaplan, S., 2015. Strategy tools-in-use: A framework for understanding "technologies of rationality" in practice. Strategic Management Journal, 36(4), 537-558.

Laamanen, T., 2017. Reflecting on the past 50 years of Long Range Planning and a research agenda for the next 50. Long Range Planning, 50(1), 1-7.

Leiblein, M. J., Reuer, J. J., \& Zenger, T., 2018. What makes a decision strategic? Strategy Science, 3(4), 558-573.

Nickerson, J. A., \& Zenger, T. R., 2004. A knowledge-based theory of the firm-The problemsolving perspective. Organization Science, 15(6), 617-632.

Ritchey, T., 2013. General morphological analysis. A general method for non-quantified modelling. Revised paper. Swedish Morphological Society. Retrieved from http://www.swemorph.com/ma.html

Ritchey, T., 2015. Principles of cross-consistency assessment in general morphological modelling. Acta Morphologica Generalis, 4(2),1-20.

Rivkin, J. W., 2000. Imitation of complex strategies. Management Science, 46(6), 824-844.

Simon, H. A., 1962. The architecture of complexity. Proceedings of the American Philosophical Society, 106(6), 467-482. 
Spee, A. P., \& Jarzabkowski, P., 2009. Strategy tools as boundary objects. Strategic Organization, 7(2), 223-232.

Steward, D. V., 1981. The design structure system: A method for managing the design of complex systems. IEEE transactions on Engineering Management, EM-28(3), 71-74.

Van den Steen, E., 2017. A formal theory of strategy. Management Science, 63(8), 2616-2636.

Vuorinen, T., Hakala, H., Kohtamäki, M., \& Uusitalo, K., 2018. Mapping the landscape of strategy tools: A review on strategy tools published in leading journals within the past 25 years. Long Range Planning, 51(4), 586-605. 
Figure 1: Lower the level of abstraction to identify the interdependent sub-choices

\begin{tabular}{|c|c|c|}
\hline & Design choices & Sub-choices \\
\hline & Arena & What range of offerings? \\
\hline & Where should focal B-school & What formats of offerings? \\
\hline & disruption? & What range of customers? \\
\hline & & What segments of customers? \\
\hline & & What content? \\
\hline & & What level of prestige? \\
\hline Strategic problem & win customers, given digital & \\
\hline & disruption? & What level of convenience? \\
\hline $\begin{array}{l}\text { How should focal B-school } \\
\text { respond to digital disruption to }\end{array}$ & & What level of fees? \\
\hline profitable way? & & Wr- 1 - \\
\hline & Value creation model & What technology? \\
\hline & How should focal B-school & What if any partnerships? \\
\hline & disruption? & What if any outsourcing? \\
\hline & & What faculty? \\
\hline & antangundal & What payment model? \\
\hline & & \\
\hline & How should focal B-school & What markup? \\
\hline & disruption? & What, if any, production \\
\hline & & \\
\hline & & What sources of income? \\
\hline
\end{tabular}


Figure 2: Combine sub-choices into a consistent choice configuration: Example of the arena.

\begin{tabular}{|c|c|c|c|c|c|c|c|c|c|c|c|}
\hline \multirow{2}{*}{\multicolumn{2}{|c|}{$\begin{array}{l}\text { Cross-consistency assessment of the arena's sub- } \\
\text { choices }\end{array}$}} & \multicolumn{3}{|c|}{ Offerings formats } & \multicolumn{4}{|c|}{ Customer range } & \multicolumn{3}{|c|}{ Customer segments } \\
\hline & & $\begin{array}{l}\begin{array}{l}\text { Only } \\
\text { services }\end{array} \\
\end{array}$ & $\begin{array}{l}\text { Both } \\
\text { services and } \\
\text { services-as- } \\
\text { a-product } \\
\end{array}$ & $\begin{array}{l}\text { Only } \\
\text { services-as- } \\
\text { a-product }\end{array}$ & $\begin{array}{l}\text { Only } \\
\text { students }\end{array}$ & $\begin{array}{l}\text { Students and } \\
\text { businesses }\end{array}$ & $\begin{array}{l}\text { Students and } \\
\text { schools }\end{array}$ & $\begin{array}{l}\text { Students, } \\
\text { businesses } \\
\text { and schools }\end{array}$ & $\begin{array}{l}\text { Only top } \\
\text { segment }\end{array}$ & $\begin{array}{l}\text { Top and } \\
\text { middle } \\
\text { segment }\end{array}$ & $\begin{array}{l}\text { Whole } \\
\text { market }\end{array}$ \\
\hline \multirow{3}{*}{ Offerings range } & Only education & $\mathrm{V}$ & (v) - & $\mathrm{V}$ & $\longrightarrow \mathrm{V}$ & & (v) & & $\Rightarrow \mathrm{V}$ & (v) & $\mathrm{V}$ \\
\hline & Education and coaching & $\mathrm{v}$ & $\mathrm{V}$ & $\mathrm{v}<2$ & $2 a v$ & & & & $\mathrm{~V}$ & $\mathrm{v}$ & $\mathrm{V}$ \\
\hline & $\begin{array}{l}\text { Education, coaching, and } \\
\text { consulting }\end{array}$ & $\mathrm{v}$ & $\mathrm{V}$ & $\mathrm{v}$ & & $\mathrm{v}$ & & $\mathrm{v}$ & $\mathrm{v}$ & $\mathrm{v}$ & $\mathrm{v}$ \\
\hline \multirow{3}{*}{ Offerings formats } & Only services & & & & $\mathrm{v}$ & $\mathrm{v}$ & & & $\mathrm{v}$ & $\mathrm{v}$ & \\
\hline & $\begin{array}{l}\text { Both services and services- } \\
\text { as-a-product }\end{array}$ & & & & $\mathrm{v}$ & $\mathrm{v}$ & (v) & $\mathrm{v}$ & & (v) & $\mathrm{v}$ \\
\hline & Only services-as-a-product & & & & $\mathrm{v}$ & $\mathrm{v}$ & $\mathrm{v}$ & $\mathrm{v}$ & & & $\mathrm{v}$ \\
\hline \multirow{4}{*}{ Customer range } & Only students & & & & & & & & $\mathrm{v}$ & $\mathrm{v}$ & $\mathrm{v}$ \\
\hline & Students and businesses & & & & & & & & $\mathrm{v}$ & $\mathrm{v}$ & $\mathrm{v}$ \\
\hline & Students and schools & & & & & & & & $\rightarrow \mathrm{V}$ & (v) & $\mathrm{v}$ \\
\hline & $\begin{array}{l}\text { Students, businesses, and } \\
\text { schools }\end{array}$ & & & & & & & & $\mathrm{S}_{\mathrm{v}}$ & $\mathrm{v}$ & $\mathrm{v}$ \\
\hline
\end{tabular}


Figure 3: Combine choices into a consistent strategy-configuration

\begin{tabular}{|c|c|c|c|c|c|c|c|c|c|c|c|c|}
\hline \multirow{2}{*}{\multicolumn{2}{|c|}{$\begin{array}{l}\text { Cross-consistency assessment of strategic } \\
\text { choices }\end{array}$}} & \multicolumn{3}{|c|}{ Customer Value Proposition } & \multicolumn{4}{|c|}{ Value Creation Model } & \multicolumn{4}{|c|}{ Value Capture Model } \\
\hline & & $\begin{array}{l}\text { Super- } \\
\text { premium } \\
\text { proposition }\end{array}$ & $\begin{array}{l}\text { Premium } \\
\text { proposition }\end{array}$ & $\begin{array}{l}\text { Value for } \\
\text { money } \\
\text { proposition }\end{array}$ & $\begin{array}{l}\text { Classic } \\
\text { campus } \\
\text { model }\end{array}$ & $\begin{array}{l}\text { Blended } \\
\text { model }\end{array}$ & $\begin{array}{l}\text { Digital } \\
\text { platform } \\
\text { model }\end{array}$ & $\begin{array}{l}\text { Digital } \\
\text { network } \\
\text { model } \\
\end{array}$ & $\begin{array}{l}\text { Very high } \\
\text { markup }\end{array}$ & $\begin{array}{l}\text { High } \\
\text { markup }\end{array}$ & $\begin{array}{l}\text { Large scale } \\
\text { economies }\end{array}$ & $\begin{array}{l}\text { Large scale } \\
\text { and scope } \\
\text { economies }\end{array}$ \\
\hline \multirow{4}{*}{ Arena } & Traditional arena & $\mathrm{v}$ & $\mathrm{v}$ & & & & & & & & & \\
\hline & e other $s$ & & (v) & $\mathrm{v}$ & & & & $\mathrm{v}$ & & (v) & $\mathrm{v}$ & \\
\hline & Expand with coaching offerings & 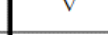 & 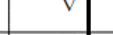 & & & & & & & & & \\
\hline & $\begin{array}{l}\text { Diversify to new offerings and } \\
\text { customers }\end{array}$ & $\mathrm{v}$ & $\mathrm{v}$ & $\mathrm{v}$ & & & & & & & & \\
\hline \multirow{3}{*}{$\begin{array}{l}\text { Customer } \\
\text { Value } \\
\text { Proposition }\end{array}$} & Super-premium proposition & & & & & & & & & & & \\
\hline & Premium proposition & & & & & $\mathrm{v}$ & & $\mathrm{v}$ & $\rightarrow$ & (V) & & \\
\hline & Value for money proposition & & & & & & & & & & & \\
\hline \multirow{4}{*}{$\begin{array}{l}\text { Value } \\
\text { Creation } \\
\text { Model }\end{array}$} & Classic campus model & & & & & & & & & & & \\
\hline & Blended model & & & & & & & & & & & \\
\hline & Digital platform model & & & & & & & & & (v) & $\mathrm{v}$ & $\mathrm{v}$ \\
\hline & Digital network model & & & & & & & & & & & \\
\hline
\end{tabular}

